\title{
The Relationship Between Profitability of Banking Sector and Macroeconomic and Financial Variables: Panel ARDL Application
}

\author{
Çağatay BAŞARIR ${ }^{1}$ \\ Bandirma Onyedi Eylul University, \\ Faculty of Applied Sciences \\ Balikesir, Turkey \\ orcid.org/0000-0002-6234-0524 \\ cbasarir@bandirma.edu.tr
}

\author{
Ahmed Yusuf SARIHAN \\ Bandirma Onyedi Eylul University, \\ Faculty of Applied Sciences \\ Balikesir, Turkey \\ orcid.org/0000-0001-7119-9852 \\ asarihan@bandirma.edu.tr
}

\begin{abstract}
Banking sector is the key to financial markets especially in developing countries. The performance of the banking system, which affects all markets in terms of ensuring financial stability of the countries, is also important. In this study, the short and long term relationship between macroeconomic variables that may affect the profitability of the banks and selected ratios as financial variables have been researched. When the empirical results are examined, it is seen that all variables used in the study are statistically significant, the ratio of the non-performing loans and inflation are negatively influences the performance of banks according to the long term coefficients whereas the ratio of total credits/total assets and economic growth rates positively affects. The error correction parameter is found negative and statistically significant. Accordingly, it is seen that approximately $38,34 \%$ of the deviation from the long-run equilibrium between bank performance and total loans, non-performing loans, economic growth and inflation is eliminated in the following period.
\end{abstract}

Keywords: Banking Sector, Bank Performance, NPL, Panel Data Analysis, ARDL

\section{Introduction}

Banking sector is one of the most important sectors of financial markets. The asset size of the banking sector in Turkey is around TL 2.5 trillion as of 2016. The loans, which are one of the most important income sources of the banks, constitute about $64 \%$ of the total assets of the banks (KPMG, 2017: 4). The banking industry has showed a great performance in Turkey. Therefore, credit facilities became more reachable. When evaluated in this context, it is seen that the ratio of the non-performing loans (NPL) is an important item for the profitability of the banks. The question is how these credits will be handled by banks. Effective management of credits given by banks has emerged as a very important factor for profitability of banks. It is often seen to relate this credits' performance with competitive advantage of financial institutions (Rozzani and Rahman, 2013: 129). Managing credit risks in financial industry has a crucial role for institutions to survive and growth potential (Rufai, 2013: 1). Moreover, effective performance of financial institutions and banks means financial stability for nations (Kaaya and Pastory,

\footnotetext{
${ }^{1}$ Corresponding Author
} 
2013: 55). With all these inferences and common believe in literature; credit quality is considered as the significant indicator of financial robustness and power of banks (Boahane et.al, 2012: 6). This importance gives great focus on credit risk and its management. However, the primary business of the banks is to provide credits-loans. At this point, the problem of tracking loans arises jointly concern for financial success. Along with this perspective, our study purposes to approach the relationship between non-performing loans and financial performances of top ten Turkish Banks.

The content of this study is as follows. There is a literature review about nonperforming loans (credit risks) and bank performance to underline and understand the empirical and theoretical works in first part. Next part includes the methods and data used along with objectives, samples, tests and analyses. The last part presents the findings and concludes the study. Our examination intends to contribute to Turkish financial markets efficiency with showing the relationship between credit risks and financial performance to prevent possible problems.

\section{Literature Review}

Developments in the financial industry brought lots of actions to the banking sector. With these actions and past financial crises, banking sector became a target for the new regulations and critics from all segments of society. Thus financial institutions and managers turn their direction to risk management (Almekhlafi et.al, 2016: 58). Since the biggest service area of banks is loans/credits, the biggest risks comes from these factors and this situation uncovers the credit risk concept (Boahane et.al, 2012: 6).

Credit risk is defined as possibility or probability of financial loss if a counterparty fails to pay the debt or honor commitments of agreement (Bhattarai, 2016: 42). It is also can be explained as bank borrowers fails to meet obligations of terms (Samuel, 2015: 3). In the direction of these information, credit risk is seen as a threat to bank performance. Therefore, a lot of researches has been done on the impact of credit risk on banks performance. We observed that bank performance is measured with return on assets ratio in many researches.

Bhattarai (2016) took the data from commercial banks of Nepal, which involves six years period. With this sampling, study revealed that there is a relation between nonperforming loans which refers credit risk and bank performance which is measured by return on assets. A regression model was applied in the study. The model showed that non-performing loans had an impact of negativity on bank performance and were statistically significant. After finding relationship between variables, study inferred that commercial banks have poor credit risk management applications.

Almekhlafi et.al. (2016) has a study on the determinants of bank performance. Study uses non-performing loans, ratio of total loans on total assets, GDP growth rate and consumer price index variables to examine their relationship between banks' performance which is measured with return on assets. The study took the data of Yemen Banks between 1998-2013 years. After regression tests, results showed that NPL ratio is a reason to volatility for bank performance. When looking at the correlation results, it is seen that good credit risk management induces high profitability.

Samuel (2015) investigated the impact of credit risk on Nigerian commercial banks' performance. NPL and LA ratios are used to measure credit risk and ROA is used to refer bank performance. After ordinary least square test method, findings revealed that banks performance is adversely affected by the LA level and NPL level. 
Berrios (2013) used the data of 200 banks and financial data set between 20052009 years to observe the relationship between credit risk and bank performance. Covariance models used in the study with ordinary least squares involving fixed effects for categorical variables. Credit intensity is considered as a risk and counted as a signal of lower liquidity in this research. After analyses, it is concluded that credit risk is related to the precaution of banks. According to the precaution level of banks, the effect of credit risk on bank performance may vary.

Kaaya and Pastory (2013) used panel data of the Tanzanian Banks. Study employed VIF (Variance Inflation Factor) and DW (Durbin Watson) tests. Also regression analysis is used for the reason that the study investigated the relationship between variables. Non-performing loans and total loan ratios are found adversely effective on banks profitability since they showed negative coefficients.

Madushani and Madurapperuma (2016) used ROA as an indicator of performance and took NPL ratio, capital adequacy ratio (CAR) with total loans to deposits ratio (LTDR) as credit risk indicators. Study found that non-performing loans has a negative impact on bank profitability.

Boahane et.al. (2012) investigated the relationship between credit risk and profitability of Ghana banks. The study showed a positive significant relationship between credit risk and bank profitability. The study line up with high default risk causes high profitability due to high interest rates.

Rufai (2013) uses the data from the secondary sources (annual reports etc.) to make a simple linear regression and Pearson coefficient for correlation to test the effect of credit risk on banks performance. It is conclude that credit risk affects the performance of banks and emphasizes a more efficient risk management philosophy for collateral security.

Bertin et.al (2014) emphasizes the factors effecting banks performance. The research takes return on assets as the measurement of performance of banks and credit risk as one of the factors effecting bank performance. Accordingly, they found that Latin American Banks' performance is negatively affected by credit risk.

Klein (2013) studied on assets' quality and profitability of banks. In this study it is strongly highlighted that non-performing loans make banks vulnerable to risks and financial shocks. The study found that non-performing loans affect banks according to the size of banking activities. Also it is inferred from the study that banks with high profitability has lower NPL ratio. In addition, providing more credits to financial markets is found to be significantly relative with higher NPL ratios.

As known by previous literature, losses from credits have economic effects on banking sector (Cantrell et. al, 2013: 148). It is found that historical credit costs are good predictors of credit risks and that costs comes from non-performing loans. Results show us a reason to determine its effects on bank profitability. Ellul and Yerramilli (2013: 1795) emphasize the importance of credit risk management and focused on nonperforming loans to measure credit risk. After the examinations, study shows that banks with lower non-performing loans have high profitability and low risks.

Chang (2006) examined the impact of selected ratios on banking industry. Study used VAR estimation model and Granger causality tests. With this study, it is concluded that NPL ratio has an impact on banking industry through ratios showing asset quality, but that effect may change according to the market concentration. 
Yücememiş and Sözer (2011) employed least squares method to forecast nonperforming loans for credit risk. Study uses GDP and exchange rates to forecast NPL ratio. Results shows that NPL ratios is affected by past bank performances. It is also concluded that the banks manage their old credit risks with an effective way are less effected by NPL and credit risk.

Gülhan and Uzunlar (2011) used panel data analysis to determine micro and macroeconomic factors' effect on banks performance. Capital structure has found to be positively effects the bank performance while personnel cost has found to be negative. Also size of banks and governmental investments have found positively affected the bank performance. Inflation and GDP have positive effects on banks performance according to this study. Moreover non-performing loans are found to be negatively affected by banks performance; which shows problems of collecting payments from borrowers and makes bank profits lower.

Taşkın (2011) took data from banks and macroeconomic variables to determine if these factor effects bank profitability. Internal factors were selected as total loans/ total assets ratio, assets size, capital/ total assets ratio, non-performing loans ratio, personnel cost/ total assets ratio and macroeconomic variables were GDP, industry production index, interest rates, inflation rates. Study employed a model from past studies with panel data analysis. As conclusion, from macroeconomic factors only industry production index has an impact on banks profitability. On the other hand, capital structure of the banks has an impact on profitability. The study emphasizes internal factor of banks are more important than macroeconomic factors for profitability of banks. The profitability of banks is seen related to quality of assets and cost of loans.

\section{Data Sets and Methodology}

The data set and method used in the study will be discussed in detail in the following sections.

\subsection{Data Sets}

The banking sector is one of the most important elements of the financial system of every country. The study examines the relationship between the credit risks of banks and profitability situations of banks using the various ratios of deposit banks in Turkey between 1989 and 2015. Information of the data used in the study is given in Table 1. 9 banks operating in Borsa Istanbul which have non-discrete data is included in the study. Total assets of the banks used in the study represents the $81.29 \%$ of the total assets of all Turkish banks.

Table 1: Variables Used in Study

\begin{tabular}{|c|c|c|c|c|}
\hline Değişken & Abbreviation & Statement & $\begin{array}{c}\text { Data } \\
\text { Range } \\
\end{array}$ & Data Resource \\
\hline $\begin{array}{l}\text { Total Credits/Total } \\
\text { Assets }\end{array}$ & LA & Assets Quality & $1989-2015$ & $\begin{array}{c}\text { The Banks Association Of Turkey } \\
\text { Statistics Reports }\end{array}$ \\
\hline $\begin{array}{l}\text { Non Performing } \\
\text { Loans/Total Credits }\end{array}$ & NPL & Assets Quality & $1989-2015$ & $\begin{array}{l}\text { The Banks Association Of Turkey } \\
\text { Statistics Reports }\end{array}$ \\
\hline $\begin{array}{l}\text { Net Profit/Total } \\
\text { Assets }\end{array}$ & ROA & Assets Quality & $1989-2015$ & $\begin{array}{c}\text { The Banks Association Of Turkey } \\
\text { Statistics Reports }\end{array}$ \\
\hline $\begin{array}{l}\text { Economic Growth } \\
\text { Rate }\end{array}$ & GDPG & $\begin{array}{l}\text { Macroeconomic } \\
\text { Variables }\end{array}$ & $1989-2015$ & $\begin{array}{c}\text { Central Bank Of Turkey Electronic } \\
\text { Data Delivery System }\end{array}$ \\
\hline $\begin{array}{l}\text { Consumer Price } \\
\text { Index }\end{array}$ & INF & $\begin{array}{c}\text { Macroeconomic } \\
\text { Variables }\end{array}$ & $1989-2015$ & $\begin{array}{c}\text { Central Bank Of Turkey Electronic } \\
\text { Data Delivery System }\end{array}$ \\
\hline
\end{tabular}




\subsection{Methodology and Empirical Results}

In the study, short-term and long-term relationship between credit risk and profitability of deposit banks in Turkey is analyzed using panel data method. Panel data analysis gives better results than conventional times series analyzes for the reason that it includes both time dimension and section size. Therefore, the panel deals with the time series of horizontal and cross-sectional data together, it provides more variability, less linear connectivity between variables and more activity (Gujarati, 2016: 405). The basic equation used in panel data analysis techniques is shown below.

$$
Y_{i t}=\alpha+X^{\prime}{ }_{i t} \beta+u_{i t} \quad \mathrm{i}=1,2 \ldots . ., \mathrm{N} \text { ve } \mathrm{t}=1,2, \ldots ., \mathrm{T}
$$

$\mathrm{i}$, in equation 1 represents households, individuals, firms, countries, and $\mathrm{t}$ represents time dimension. Kx1 and $\mathrm{K}$ represent the I-th observation in the explanatory variable (Baltagi, 2005: 11). The estimated equation in the study is shown in Equation 2:

$$
R O A_{i t}=\alpha+L A_{i t} \beta+N P L_{i t} \beta+G D P G_{i t} \beta+I N F_{i t} \beta+u_{i t}
$$

In equation 2, ROA is the return on assets, LA is assets quality, NPL is the nonperforming loans, GDPG is the economic growth rate, INF is the inflation rate and $i$ represents the country of the data, that is the horizontal section, $t$ represents the year in which the data belongs, and $\mu$ represents the error terms.

\subsubsection{ARDL Model}

Peseran, Shin and Smith (2001) proposed a pooled average group (PMG) estimator for dynamic heterogeneous panelists, in which pooling and averaging are performed at the same time. While the estimator restricts homogeneity to long term coefficients, it allows the error correction coefficients (such as fixed effects estimator) and short terms parameters to change from unit to unit and average for all units. Under the assumption that long term coefficients are homogeneous, PMG estimators are consistent and effective when MG estimators are ineffective (Peseran, Shin and Smith, 2001: 300).

ARDL model is used (Peseran etc., 2001), where short run coefficients, the speed of adjustments and error variances are allowed to vary across the countries but the long run coefficients are the constrained to be the same. An additional advantage of this model is that it yields consistent estimates of the long run parameters irrespectively of whether the underlying regressors are stationary, non-stationary or mutually cointegrated.

\subsubsection{Panel Unit Root Tests}

One of the basic assumptions of the time series analysis requires the series to be stationary. The stability of the series is that its mean and its variance are constant over time. However, Nelson \& Plosser (1982) have observed that the majority of the macroeconomic and financial time series are generally non-stationary. The time series of this type generally have a general tendency to increase or decrease or a nonstationary tendency in the mean (Cilyavuz, 2015: 283). 
When analyzed with non-stationary time series, there is a spurious regression problem. For these reason, it is necessary to measure the stationary conditions of the series before analyzing either the time series analyzes or the panel series analyzes. Unit root test are also used in analyzing the stationary conditions of the time series. The tests used for unit root analysis are divided into two as first-generation and secondgeneration unit root tests, depending on the consideration of horizontal section dependency. While the first generation unit root tests do not consider the horizontal section dependency, the second generation unit root tests consider the horizontal section dependency.

\subsection{Empirical Results}

The stationary conditions of the series were investigated by tests developed by Levin, Lin and Chu (2002) and Im, Peseran, Shin (2003) from first generation unit root tests. Unit root test results are shown in Table 2.

When Table 2 is examined, it is seen that some of the variables are stationary at level and some of them are at first level. The panel ARDL model should be used to estimate the short-term and long-term relationship between the series for the reason that the series are stationary at different levels and none of the series is stationary at second or higher levels. In order to determine the short-term and long-term relationship between variables in the study, the system automatically selected the ARDL $(4,4,4,4)$ model. The predicted model results are shown in Table 3.

Table 2: Results Of Panel Unit Root Tests

\begin{tabular}{|l|c|l|l|l|}
\hline & \multicolumn{2}{c|}{ LLC } & \multicolumn{2}{c|}{ IPS } \\
\hline \multicolumn{1}{|c|}{ Variable } & Stable & Stable and Trend & Stable & Stable and Trend \\
\hline ROA & $-1.30436(0.0961)$ & $-0.54680(0.2923)$ & $-2.42227(0.0077)$ & $-2.11902(0.0170)$ \\
\hline LA & $2.17508(0.9852)$ & $0.37087(0.6446)$ & $2.61396(0.9955)$ & $1.57978(0.9429)$ \\
\hline NPL & $-0.95450(0.1699)$ & $0.46911(0.6805)$ & $-2.42768(0.0076)$ & $-1.40899(0.0794)$ \\
\hline GDPG & $-8.93007(0.0000)$ & $-7.31870(0.0000)$ & $-7.69899(0.0000)$ & $-5.60504(0.0000)$ \\
\hline INF & $-8.91030(0.0000)$ & $-6.34348(0.0000)$ & $-5.90763(0.0000)$ & $-1.47771(0.0697)$ \\
\hline First Differences & & & & \\
\hline ROA & $-7.45187(0.0000)$ & $-5.37690(0.0000)$ & $-8.94763(0.0000)$ & $-6.86894(0.0000)$ \\
\hline LA & $-3.78790(0.0001)$ & $-2.08413(0.0186)$ & $-5.68284(0.0000)$ & $-4.38714(0.0000)$ \\
\hline NPL & $-7.02766(0.0000)$ & $-5.08741(0.0000)$ & $-8.17814(0.0000)$ & $-6.14818(0.0000)$ \\
\hline GDPG & $-12.7541(0.0000)$ & $-11.1085(0.0000)$ & $-12.9539(0.0000)$ & $-10.9816(0.0000)$ \\
\hline INF & $0.95353(0.8298)$ & $2.85194(0.9978)$ & $3.39858(0.9997)$ & $-0.09740(0.4612)$ \\
\hline The numb & & & & \\
\hline
\end{tabular}

The numbers in parentheses indicate $p$ values. In the LLC test, Newey-West band width was selected and estimation was performed on according to Barlett kernel methods. The maximum number of delays was automatically selected and the maximum delay length was determined according to Schwarz information criterion.

First of all, the parameter of the error correction estimator is important for the consistency and validity of the model. This parameter must be negative and statistically significant. Tables 3 shows that the error correction term is statistically significant and the sign is negative, indicating that the model is valid. Therefore, when viewed from the 
panel perspective, it is seen that approximately $38.34 \%$ of the imbalance between ROA and LA, NPL, GDPG and INF is eliminated.

After unit root tests, it is necessary to test whether there is correlation between units. Correlation between the units is examined by horizontal section dependency tests. The horizontal section dependency test developed by Peseran (2004: 23) was used in the study. As a result, " $\mathrm{H}_{0}$ : There is no horizontal section dependency between the units" hypothesis is accepted ( $\mathrm{LM} \mathrm{CD}=0,549)$. Therefore, it has been determined that there is no horizontal section dependency between units.

Table 3: Panel ARDL

Model: $\operatorname{ARDL}(4,4,4,4,4)$

\begin{tabular}{cccrr}
\hline \hline Variable & Coefficient & Std. Error & t-Statistic & Prob. $^{*}$ \\
\hline \hline \multicolumn{6}{c}{ Long Run Equation } \\
NPL & -0.100311 & 0.022230 & -4.512409 & 0.0000 \\
LA & 0.040281 & 0.016527 & 2.437270 & 0.0171 \\
INF & -0.014453 & 0.005778 & -2.501525 & 0.0145 \\
GDPG & 0.941045 & 0.084736 & 11.10568 & 0.0000 \\
\hline \hline & Short Run Equation & & \\
\hline \hline
\end{tabular}

When we look at the long term coefficients in Table 3, it is concluded that all variables are statistically significant, while the coefficients of the non-performing loans variable and the inflation variable are negative. As a result, we can say that there is a relation between short-term ROA variables and other variables. In the long-run, we can say that non-performing loans and performance of banks decreases when inflation increases but the performance of banks increases when economic growth and total loans/ total assets ratio increases.

\section{Conclusion}

Credit risk is one of the most important risk type for the banking sector, where loans are the main source of income. For this reason, the banks should manage the credit risk efficiently in order to increase the profitability at sustainable levels. Risks can be eliminated by removing uncertainties generating risks. For this reason, short and long term relationships between the main macroeconomic variables affecting the profitability of the deposit banks, which represents $80 \%$ of the total assets of the banking sector in Turkey, are investigated. Relationship between the variables in the study are estimated by a Panel ARDL model.

This study shows that there is a significant relationship between bank performance (profitability) and non-performing loans (credit risk). We revealed that when the credit risk increases, there will be a decrease in bank performance. Thus, it is of crucial importance that banks pay attention on their non-performing loans and risks about loans. Since there is a risk of receivables not being collected, credit risk (nonperforming loans) stands out as a remarkable subject for academicians and managers of financial sector. Credit risk management must be handled with importance due to its impacts on profitability. 


\section{References}

Almekhlafi, E., Almekhlafi, K., Kargbo, M., \& Hu, X. (2016). A Study of Credit Risk and Commercial Banks' Performance in Yemen: Panel Evidence. Journal of Management, 4(1), 57-69.

Baltagi, B.H., 2005. Econometric analysis of panel data. 3rd Edn., USA: John Wiley\&Sons

Bertin, M., Arias Moya, J., \& Rodriguez Perales, A. (2014). Determinants of bank performance: evidence for Latin America. Academia Revista Latinoamericana de Administración, 27(2), 164-182.

Berríos, M. R. (2013). The relationship between bank credit risk and profitability and liquidity. The International Journal of Business and Finance Research, 7(3), 105118.

Bhattarai, Y. R. (2016). Effect of Credit Risk on the Performance of Nepalese Commercial Banks. NRB Economic Review.

Boahene, S. H., Dasah, J., \& Agyei, S. K. (2012). Credit risk and profitability of selected banks in Ghana. Research Journal of finance and accounting, 3(7), 6-14.

Cantrell, B. W., McInnis, J. M., \& Yust, C. G. (2013). Predicting credit losses: Loan fair values versus historical costs. The Accounting Review, 89(1), 147-176.

Chang, Y. T. (2006). Role of Non-Performing Loans (NPLs) and Capital Adequacy in Banking Structure and Competition. Economic \& Social Research Council. Center for Competition Policy. ISSN, 1745-9648.

Çil Yavuz N., "Finansal Ekonometri", DER Yayınları, İSTANBUL, 2014, p.283.

Ellul, A., \& Yerramilli, V. (2013). Stronger risk controls, lower risk: Evidence from US bank holding companies. The Journal of Finance, 68(5), 1757-1803.

Gujarati, Damodar (2016), Örneklerle Ekonometri, Çev. Nasip Bolatoğlu, 2. Bask1, Palgrave Macmillan Pres.p. 405.

Gülhan, Ü., \& Uzunlar, E. (2011). Bankacılık Sektöründe Kârlılığı Etkileyen Faktörler: Türk Bankacılık Sektörüne Yönelik Bir Uygulama/Factors Influencing the Bank Profitability: an Apllication on Turkish Banking Sector. Atatürk Üniversitesi Sosyal Bilimler Enstitüsü Dergisi, 15(1).

Im, K.S., M.H. Pesaran and Y. Shin, (2003), "Testing for unitroots in heterogeneous panels", Journal of Econometrics, Cilt. 115, Say1. 1, (53-74).

Kaaya, I., \& Pastory, D. (2013). Credit risk and commercial banks performance in Tanzania: A panel data analysis. Research Journal of Finance and Accounting, 4(16), 55-62.

Klein, N. (2013). Non-Performing Loans in CESEE: Determinants and Macroeconomic Performance IMF Working Paper. WP13/72.

KMPG, (2017). Sektörel Bakış Bankacılık, 1-9 https:/home.kpmg.com/tr/tr/home/insights/2017/01/sektorel-bakisbankacilik.html. (10.04.2017) 
Levin, C.F. Lin and C.S.J. Chu, 2002. Unit root tests in panel data: Asymptotic and finite-sample properties. Journal of Econometrics, Cilt.108, Say1.1, (1-24).

Madushani, B. D. A., \& Madurapperuma, M. W. (2016). The Relationship between Credit Risk and Bank Performance: A Study of Commercial Banks in Sri Lanka. 2. International Conference for Accounting Researchers and Educators Proceedings

Nelson, C. R., and Plosser, C. R. (1982). Trends and random walks in macroeconomic time series: some evidence and implications. Journal of monetary economics, $10(2), 139-162$.

Pesaran, M. H. (2004). General diagnostic tests for cross section dependence in panels.

Pesaran, M. H, Shin, Y, Smith, R. J.(2001). Bounds testing approaches to the analysis of level relationships. Journal of Applied Econometrics, Vol. 16, p. 289-326.

Rozzani, N., \& Rahman, R. A. (2013). Determinants of Bank Performance: Conventional versus Islamic. Jurnal Pengurusan, 39, 129-139.

Rufai, A. S. (2013). Efficacy of Credit Risk Management on the Performance of Banks in Nigeria A Study of Union Bank PLC (2006-2010). Global Journal of Management and Business Research Administration and Management, 13(4).

Samuel, O. L. (2015). The effect of credit risk on the performance of commercial banks in Nigeria. African Journal of Accounting, Auditing and Finance, 4(1), 29-52.

Taskin, F. D. (2011). Türkiye'de Ticari Bankalarin Performansini Etkileyen Faktörler/The Factors Affecting The Performance of The Turkish Commercial Banks. Ege Akademik Bakis, 11(2), 289.

Yücememiş, B.T. \& Sözer, İ.A. (2011) Bankalarda Takipteki Krediler: Türk Bankacılık Sektöründe Takipteki Kredilerin Tahminine Yönelik bir Model Uygulaması, Finansal Araştırmalar ve Çalışmalar Dergisi, Cilt:3, Sayı: 5. 